\title{
Motivations: When Conflict Leads to Litigation
}

What motivates political actors to engage in European Union annulment litigation? This is the main question studied in this chapter. Our starting point is the observation that it is not possible to reduce public actors' decisions to initiate annulment actions to the pure legal characteristics of the cases. Annulment actions do not automatically arise from specific legal circumstances. This is what we learn from the examples of annulments reported in the previous chapters. There is more to filing an annulment lawsuit then just a legal-technical quarrel. This more is the political context that surrounds a concrete decision to engage in annulment litigation.

While never contradicting the legal logic of annulment litigation, actors chose from the universe of potential annulment conflicts to engage in due to political reasons, which we conceive as material gains, institutional competences, ideology, or political trust. Consider in this context that annulment litigation is a defence against decisions made by an EU institution; such a supranational decision, if it remains unchallenged, constitutes a final point in a struggle about particular policy choices. In other words, if actors do not take up the fight-that is, if nobody litigates - the current interpretation of the supranational measure adopted prevails. It marks the institutional endpoint of a conflict, which can then have feedback effects. Actors obviously can choose not to engage in annulment conflict, but if their choice is to do so, it is the context of the struggle they go through in the multilevel policy

(C) The Author(s) 2020

C. Adam et al., Taking the EU to Court, Palgrave Studies in European Union Politics, https://doi.org/10.1007/978-3-030-21629-0_5 
process - their priorities, perceived needs, and subsequently the utility they associate with potentially successful litigation-that tip them into active litigation.

It is thus important to uncover litigants' motivations behind the empirical decision to turn to court. To this aim, we first review the literature on judicial politics as well as the classical literature on actors' motivations. On this basis, we distinguish between four types of motivations that drive actors to initiate annulment lawsuits in EU Court: to maximize financial resources, institutional power, ideological and policy preferences, and political trust.

Second, based on extensive fieldwork carried out in Germany, Spain, and Brussels, this chapter assesses the relevance of these four motivations for launching annulment litigation empirically in selected cases (see also Chapter 4). Rather than classical ideal types in the Weberian sense, the four motivations are real types. Empirically, decisions to start an annulment case can be based upon several motivations simultaneously. ${ }^{1}$ As we will show when analysing individual annulment cases, for almost all of them, a dominant motivation can be identified. We find, however, that not all motivations occur with equal frequency and that certain types of actors are associated more frequently with some motivations than with others.

First, financial gains are the most important motivation in quantitative terms, they underpin the bulk of annulment actions. Litigation is chosen when legal success would significantly improve the litigant's budget by either avoiding substantial expenses or maximizing revenue. Financial motives are important not only for private actors, such as companies having benefitted from state aid. They are also a crucial motivation for public actors, that is, member states and subnational authorities in the face of a Commission decision of financial correction in agriculture or cohesion policies. This type of motivation is generally associated with supranational decisions bearing little saliency, and often do not have much impact beyond the financial redistribution across levels-although they can also occasionally come with important policy change in the related sectoral policies, such as the common agricultural policy or cohesion policies.

Second, litigation is pursued when the Court's interpretation of unclear legal concepts may significantly improve the litigant's institutional and decision-making competences. This motivation is found almost exclusively among public actors, both national and European, to 
counter measures they perceive as a competence stretch threatening to reduce their own institutional power. This motivation is typically found with annulment actions that have important EU-wide repercussions, because they always bear a potential to alter the institutional status quo through a Court-led redefinition of competences within the EU.

With respect to the third motivation-ideology-litigation represents an opportunity to defend or promote an important ideological aspect or policy position by establishing or keeping a normative order. In terms of numbers, this motivation was not very significant. It was not found with that much frequency as the other three and we rather observed it occasionally. Interestingly, we found that this motivation tends to underpin conflicts in highly salient policy issues.

Finally, litigation can also be used as a political symbol to signal responsiveness and trustworthiness to the litigant's constituency and to important political partners. While overall less important empirically, a specificity of this motivation is the type of actor likely to initiate it. It matters for actors who are directly elected at the subnational, national, or supranational level, such as governments or, less frequently, the European Parliament (EP). Typically, the stakes underpinning this type of motivations are national or even local. So this type of action tends to have a significant distributive impact on national or local actors. While they can have EU-wide repercussions, this is not always the case.

The following analyses of empirical cases will demonstrate that annulment actions are regularly used for political purposes. They are inherently political tools employed as strategies in policy conflicts in the EU multilevel system. How the legal background mediates the political motivations to initiate annulment actions is thus a central puzzle to which this chapter now turns. In sum, the following pages shed light on the constellations, conditions, and mechanisms that bring actors to pursue their objectives with the help of annulment actions.

\section{Conceptualizing Motivations for Litigation}

Since Martin Shapiro's (1964) seminal introduction of a research agenda for political jurisprudence, the study of courts and litigation has escaped the narrow confines of legal scholarship. Since then, various social science disciplines have applied their concepts, theories, and methods to the study of judicial processes. This allowed grasping the non-legal dimension of judicial proceedings, such as actors' decisions to litigate 
and judges decision-making roles. The literature on judicial politics thus offers plenty of material that is potentially relevant for studying annulment actions. We have complemented this body of literature with insights from research on actors' motivations and preferences. This section presents a theoretically derived categorization of four types of motivations for litigation, extensive enough to do justice to extant research and yet parsimonious enough to be a useful tool in empirical research.

\section{Material Gains}

The first of these motivations is all about material-more precisely, financial-resources. Actors litigate because they hope to gain financial resources or avoid their loss. This motivation is particularly prominent for private litigators, as economic research on litigation has emphasized (Gould 1973; Posner 1973; Bebchuk 1984; Priest and Klein 1984). This literature typically investigates the conditions for the use of different conflict-resolution mechanisms by opposing parties, litigation being one, arbitration another. These works assess how a variety of factors (e.g. information asymmetry, judicial procedures, probability to win) affect the risk-benefit analysis made by litigants when deciding whether it is financially worthwhile to go to court. This literature thus assumes that litigation is driven primarily by financial considerations and leaves little room for other possible rationales regarding the use of litigation.

Wealth maximization is obviously of particular relevance for understanding the behaviour of private actors attempting to further their economic aims with the help of litigation. But public actors, too, care about their budgets. In contrast to the economic literature that focuses on individuals' material interest, for public actors, material motivations are typically studied in combination or alongside other motivational factors. Depending on the conceptualization of the role models of bureaucrats, individual material gains can be crucial to explaining public decisions (Downs 1967). Moreover, at an aggregate level, bureaucracies are often conceived as self-aggrandizing actors, searching to maximize their budget and expand their services (Niskanen 1971). This assumption also applies to governments whose capacity to act depends-inter alia-on the national budget. Given the political relevance of budgets, politicians are thus searching to maximize revenues (Brennan and Buchanan 1980) and to limit unnecessary or non-priority expenses. 
Many decisions adopted in the EU multilevel system have a budgetary impact. Furthermore, as in any polity, EU budget decisions are subject to intense inter-institutional conflicts (Becker et al. 2017), which often lead to the use of judicial review, especially by the Council against decisions of the EP (Skiadas 2002). The Commission, too, may adopt decisions that affect member states' budgets in a negative way (Bauer and Becker 2014; Ege et al. 2018). The treaties and secondary law have delegated a series of sector-and issue-specific enforcement mechanisms to the Commission-other than the infringement procedure (Gil Ibañez 1998) - allowing the latter to impose financial sanctions on the member states. Judicial review may then be used by the member states to challenge these decisions (Bauer and Hartlapp 2010). We expect such a material motivation to be particularly relevant in EU policy areas where distributive instruments prevail or where regulatory instruments directly affect the allocation of resources. The maximization of material resources can explain annulment actions initiated by EU institutions or by the member states, where the litigant is willing to annul a decision that has a negative impact on its budget or to seek higher budgets, without necessarily being the only reason for engaging in annulments (as we shall see below). The motivational logic behind trying to protect or expand one's material resources, however, is simple: annulment actions motivated by financial resources aim at revoking a decision of EU institutions that has a negative impact on the litigant's budget. In short, the object to litigate is to receive a favourable decision about an actor's own material gains.

\section{Institutional Competences}

In his seminal work on the functioning of democracies, Downs (1957) argues that political actors are not interested in particular policies. Instead, they care about the privileges they derive from holding power. Thus, what motivates them is institutional power and positions. This motivation is likely to matter for annulment conflicts in the EU multilevel system, too. Litigation can be motivated by the intention to influence the distribution of institutional competences in a political system. We know that courts can have a profound impact on the structure of governance and politics, that is, on the distribution of power among political actors and their strategic behaviour and interactions. Stone Sweet's (1999) theory about the judicialization and the construction of 
governance and Jupille's (2007) argument about contested legislative procedures highlight the endogenous process through which the characteristics of a polity can be altered gradually and even profoundly through actors' recourses to litigation. Actors may thus resort to litigation in the hope to use the court's influence as a lever to alter the distribution of institutional competences to their advantage.

In federal states, courts have significant influence on the shape and evolution of the multilevel decision-making arrangement (Baier 2006). Hence, judicial review plays a particularly important role in federal countries. Comparative politics and legal scholarship understand it as a tool that allows protecting the constitutionally enshrined federal arrangements against attempts by the federal or regional governments to overstep each other's competences (Lijphart 1999; Baker and Young 2001; Ryan 2011). Courts' capacity to shape federal arrangements is particularly prominent in countries with a high number of veto players in the executive and legislative branches (Swenden 2006, 79). Being a highly fragmented polity, the EU appears particularly prone to judicial influence on the distribution of power between the supranational and national level. After all, the Court of Justice of the European Union (CJEU) has come to be seen as capable of transforming the relationship between the EU's and national legal orders in fundamentals ways for a long time (Burley and Mattli 1993; Stone Sweet and Brunell 1998).

Moreover, legal provisions-and particularly constitutional provisions - that define the distribution of competences are conventionally theorized as incomplete contracts (Farrell and Héritier 2007) that can be-or sometimes even need to be-clarified via litigation (Hadfield 1994). By inviting the judiciary to (re-)interpret the legal provisions specifying the distribution of competences on which a contested act was based, litigants might manage not only to dissolve the contested legal act, they might also be able to create an effective (legal) barrier that will keep the defending institution from adopting similar legal acts in the future. In this sense, litigation today can be initiated with the goal in mind of avoiding similar competence creep in the (far) future.

This motivation is likely to matter for two reasons, both related to systemic features of the EU. First, part of the EU's expansion of powers is the result of competence creep, in particular as provoked by the Commission (Pollack 1994; Weatherill 2004; Amaral and Neave 2009; Prechal 2010). Second, the high number of veto players involved in EU decision making makes it difficult for the member states to counteract, 
through the adoption of legislation or treaty change, the Commission's decisions once such a decision is taken (or those of other EU institutions). This turns the CJEU into an attractive venue for member states willing to put a hold on the Commission's extensive interpretation of the EU's competences (see Schmidt 1998, 173; Bauer and Hartlapp 2010). In line with this argument, Adam $(2016,158)$ argues that governments may use annulment actions 'for reasons that go beyond the desire to win a legal dispute [...] and instead [...] to bring more general questions concerning the design of institutions [...] to the CJEU's attention', in the hope of exploiting the Court's judicial authority to alter the EU's institutionalized balance of power. In short, annulment actions are launched as an attempt to influence the distribution of institutional competences in the long term via inviting the CJEU to formulate a judicial interpretation of key legal concepts. We thus expect to see conflicts motivated by an interest in keeping or expanding competences, particularly in those policy areas and in those periods of time where competence allocation in the multilevel system changes or where competences are shared between institutions and levels. This motivation should be most relevant for public actors as their relationships and (future) checks and balances in a political system will be at stake. We refer to this kind of institutional motivation as the willingness to protect decision-making competences.

\section{Ideology}

Next to material gains and protecting institutional competences, a decision to litigate can also emerge from substantial policy interest. Going back to the early literature on political parties, Edmund Burke established the notion that groups of political actors are motivated by some principle in which they all agreed. The ideological orientation of a group can explain the positions chosen in line with such principles. Moreover, comparative politics research (De Swaan 1973; Müller and Strøm 1999) argues that the party political orientation of actors helps to explain why actors are seeking specific policies. Where this ideology is at odds with a process or instrument chosen, or where it does not fit the substance of an EU policy, conflict can emerge. In such a case, the active engagement in this conflict is driven by neither a material motivation nor an institutional motivation. Ideology can be a reason for actors to take decisions that are not in their material or institutional interest. Instead, values and norms about how things ought to be can be powerful drivers of agency. 
In European integration research, the role of national interests has been heatedly debated ever since the early days of theorizing supranational institution building. Prominently, national positions are explained by particular policy interests, such as preferences for creating an internal market expressed by national economic elites (Moravcsik 1991). However, ideology is also an important explanation for European integration and for policies adopted in the EU system. Normative beliefs and deeply rooted values not only shape individual behaviour but may prevail at the level of collective actors or even entire nations, for example regarding nation-state identity, (Western liberal) values, and a shared understanding of human rights and the rule of law. Ideology motivates actors to propose and use EU instruments. Where this ideology is at odds with a process or instrument chosen or where it does not fit with the substance of an EU policy, conflict can emerge (Risse et al. 1999).

Policy actors may try to use litigation as a tool to advance their substantial policy goals. The extensive literature on the legal mobilization of social movements developed in the United States shows how litigation can serve ideologically driven actors (Scheingold 1974; McCann 1994). Similar results are found in the EU, where both gender rights activists and environmental organizations have used litigation strategies before the European Court of Justice as a mean to advance their policy agenda (Cichowski 2007). Yet this motivation for litigation is not exclusively reserved for social movements and non-governmental organizations. Ideology is also an important driver for national governments, the Council, the EP, and the European Commission. While it remains difficult to apply the notion of party families across all EU member states (Camia and Caramani 2012), the politicization of European integration has turned ideology into an important determinant of EU policy making (Hutter and Grande 2014; Hartlapp 2015; Rauh 2019). The early years of integration were characterized by a permissive consensus, where integration advanced without (public) contestation as an elite project (Hooghe and Marks 2009). This has started to change in the 1990s, and today, political contestation affects virtually all EU institutions. An increasingly critical public challenges specific EU policies as well as the overall direction of the integration process. There is more debate about desirable trajectories for European integration. Frequently, criticism and controversy follow party cleavages. The desire to defend policy design often motivates annulment actions against decisions of EU institutions that appear to come in the way of achieving ideological goals. 
When a decision adopted by an EU institution clashes with a public actor's ideological preferences, we can imagine ideology motivating actors to raise an annulment action with a view to having the EU measure annulled. Such action may have, as a priority objective, the annulment of the contested EU measure.

Even more so, annulment actions may also serve long-term ideological goals reaching well beyond the case at hand. Indeed, litigation can be 'more than just litigation and courts' (Boutcher 2013), as is shown by the constitutive approach to legal mobilization by social movements (McCann 1994). Similar to what we discussed regarding a long-term institutional motivation, annulment litigation may also serve long-term ideological goals simply by subjecting legal concepts with ideologically important implications to judicial review. These ideologically important concepts become part of legal discourse. The prevailing legal interpretation turns the litigation on which it is based into a 'prophetic litigation' that 'often functions as an appeal to future generations' (Lobel 1995, 1347), 'to the brooding spirit of the law, to the intelligence of a future day, when a later decision may possibly correct the error into which the dissenting judge believes the court to have been betrayed' (Hughes $1928,68)$. In other words, the contested case creates opportunities in the sense of Galanter's repeat players argument, according to which institutional actors often engage in litigation with the view of shaping courts' case law in the long run rather than in the tangible outcomes of specific cases (Galanter 1974). In the same line of reasoning, Granger's account of member states' participation to preliminary references trials emphasizes their willingness to weigh on the evolution of the Court's legal doctrine in the long run (Granger 2004). Ideology may thus motivate actions that can have, as a primary purpose, either the annulment of the contested EU measure or the promotion of a legal discourse supporting the litigants' normative order. In sum, annulment actions can be motivated by the goal to revoke EU measures that clash with the litigant's ideological preferences.

\section{Political Trust}

Scholarship on the strategies of social movements to mobilize against regulations argues that litigation, independent from the outcome of the trial, can increase social movements' credibility and public support (Lobel 1994; McCann 1998; NeJaime 2011). By initiating judicial 
proceedings, a social movement may attempt to change the public's perception about its action and to gain the public's trust, sympathy, and support. This mechanism can be an appealing way to signal trustworthiness to important constituencies for politicians and governments and should help to improve their chances for reelection (Müller and Strøm 1999). It is thus a form of legitimacy. Interestingly, in this case, the initiation of litigation is sufficient for gaining political trust and electoral support. The legal outcomes of judicial proceedings play only a secondary role, particularly when they materialize only after several years of proceedings.

Political trust, as we conceive it, is a highly valuable resource for office holders because it translates into citizens' support for their policies (Chanley et al. 2000; Davis and Silver 2004; Hetherington 2005; Rudolph and Evans 2005). Political trust also increases political actors' informal room for manoeuvre and thereby can smoother the functioning of the political system (Miller 1974; Coleman 1994; Gambetta 1998; Levi and Stoker 2000), as well as the chances for being reelected. It should thus not be surprising that political leaders eagerly invest continuous effort in maximizing political trust (Bourdieu 1991, 18).

Obviously, political trust is affected by many parameters, including the perceived quality of democratic institutions (Mishler and Rose 2001; Segovia Arancibia 2008), demographic variables (Christensen and Laegreid 2005; Macoubrie 2006), societal characteristics (Newton and Norris 1999), and exogenous events and the saliency of international issues (Chanley 2002; Hetherington and Rudolph 2008). Moreover, governmental performance (Citrin 1974; Hetherington 1998; Chanley et al. 2000; Van De Walle and Bouckaert 2003; Keele 2007), the alignment between the policies adopted and the public's preferences (Miller 1974), and leaders' personality (Citrin 1974; Citrin and Green 1986) affect levels of political trust.

As a matter of fact, it is less the objective governmental performance, responsiveness, and leadership per se than it is the public's perception of these aspects that affects political trust. Trust is a relational concept; to be trusted, trustees need to signal trustworthiness to their principals (Bacharach and Gambetta 2001). This is a sociological mechanism that applies in a wide variety of situations. Companies use third-party certification labels to signal trustworthiness (Aiken et al. 2004); bureaucracies design their public communication in order to improve their 
reputation-that is, the public's perception of their capacities and performance (Maor et al. 2013). Just as companies and bureaucracies do, politicians also need to convince their own audience, their constituency, of their trustworthiness.

While political trust as a relationship is important for any actor in a political system, electoral gains are particularly relevant where we can identify a constituency. This is the case for national governments as well as for the EP. They all need to take care of the image they send to their voters. Litigating against (other) EU institutions can be a way to signal trustworthiness to constituencies. Political parties can thereby demonstrate their willingness to "stand up and fight" for the rights and interests of their electorates. By litigating against legal acts that clash with public opinion, national governments, as well as members of the EP, can show their responsiveness to the public's concerns. Consequently, we speak of responsiveness and trustworthiness whenever the motivation to litigate is driven by the attempt to retain a good relationship with the public.

Table 5.1 depicts the four motivational logics for initiating an annulment action that we derive from our reading of the pertinent literature. The question, however, is whether these motivations drive empirical cases. It is thus to the analysis of annulment cases that we now turn.

Table 5.1 Overview of the four motivational logics for litigation

\begin{tabular}{|c|c|c|}
\hline Motivations & Objective & $\begin{array}{l}\text { How does litigation serve the } \\
\text { actor's objective? }\end{array}$ \\
\hline Material gains & $\begin{array}{l}\text { Maximising returns or minimizing } \\
\text { costs }\end{array}$ & $\begin{array}{l}\text { Repealing a decision that has a } \\
\text { negative impact on the litigant's } \\
\text { budget }\end{array}$ \\
\hline $\begin{array}{l}\text { Institutional } \\
\text { competences }\end{array}$ & $\begin{array}{l}\text { Preserving political rights and } \\
\text { ring-fencing the opponent's deci- } \\
\text { sion-making competences }\end{array}$ & $\begin{array}{l}\text { Interpretation of competences } \\
\text { and decision-making powers }\end{array}$ \\
\hline Ideology & $\begin{array}{l}\text { Promoting ideological or substantial } \\
\text { policy preferences }\end{array}$ & $\begin{array}{l}\text { Establishing or keeping norma- } \\
\text { tive orders }\end{array}$ \\
\hline Political trust & $\begin{array}{l}\text { Maintaining good relationships with } \\
\text { addressees of a policy }\end{array}$ & $\begin{array}{l}\text { Signalling responsiveness and } \\
\text { trustworthiness to constituencies } \\
\text { and partners }\end{array}$ \\
\hline
\end{tabular}

Source Own compilation 


\section{EMPIRICAL ANALYSIS}

We thus expect litigation to be driven by motivations to maximize material gains, to promote and protect one's ideological goals, to defend one's institutional competences, and to maximize political trust. Analytically, these motivations are clearly distinct. Empirically, however, it is challenging to objectively identify and distinguish these motivations. It is important to realize that these motivations are not mutually exclusive. For each case, we seek to identify the predominant motivation while also reflecting aspects of the other motivations. In addition, motivations are notoriously difficult to capture, as they cannot be directly observed. Motivations, understood as objectives an actor is seeking in the first place (and rather independently from other factors that render litigation more or less likely), can, however, be deduced indirectly from primary (interviews, rulings) and secondary sources.

\section{The Legal Factor}

The literature on the economics of litigation sees the chances of success in court as a crucial factor for deciding whether to litigate. ${ }^{2}$ After all, it is the chances of success that strongly influence litigants' expected payoffs, no matter whether these are material or immaterial. We have asked our interviewees about the role of the legal factor, understood as the chances of judicial success, in their decisions. While it plays a central role for private actors, it is apparently not so crucial for public actors. Although the member states lose most vertical conflicts (i.e. $75 \%$ of the cases in which they litigate by themselves against single EU institutions), the legal merits of the case supporting the position of the member states do play a role. State attorneys and legal services of the EU institutions need a legal doubt, however small, in order to engage in litigation. When legal defeat in court is nearly certain-that is, when the application of the Court's case law will in all likelihood imply a rejection of the annulment action-these actors rather abstain from litigating. The reason is simple. State attorneys and legal services in the EU institutions want to preserve their reputation and credibility in Luxemburg, which means they are careful not to raise actions without adequate legal justificationand at least some chances of winning. By contrast, a legal doubt (even a small one) about how case law should apply to the case at hand suffices 
to legitimize judicial action; state attorneys are in such cases very keen to litigate (MIN_ES_4, MIN_ES_5). In this sense, a legal doubt on the case is a necessary condition for litigation, but it is not a sufficient one. We now examine, based on a carefully selected series of case studies, the role of material gains, institutional competences, ideology, and political trust in motivating public actors to raise annulment actions.

\section{Material Gains-Driven Motivation in Annulment Litigation}

We claim that financial resources can play an important role in public actors' decisions to raise annulment actions. The underlying objective is to get the Court to declare void a decision that would have a negative impact on the litigant's budget. We find that this motivation is particularly important in vertical annulment conflicts, that is, in those cases initiated by (private) national or subnational litigants against EU institutions. Hence, this section essentially focuses on such vertical cases, although we also give an example of horizontal case (i.e. initiated by an EU institution) motivated by the litigant's willingness to maximize financial resources.

When member states litigate against EU institutions, many cases emerge in the context of agricultural policy and regional policy. Both the Common Agriculture Policy (CAP) and the regional policy are redistributive policies, which allocate funds to different types of beneficiaries across Europe. The application of these policies and their execution relies on the Commission's strong enforcement powers, which may adopt decisions of financial correction, where they find that EU funds are not spent according to EU law. When the sums spent under the CAP or the regional policy are advanced by the member states and reimbursed by the Commission at a later stage, by adopting a decision of financial correction, the Commission denies the transfer to the member states of the sums already issued. Annulment actions raised by the member states in both sectors typically target such Commission decisions of financial correction. This gives a first indication of the likely importance of material interests in member states' decisions to litigate against the Commission. To verify this, we asked national civil servants in Spain and Germany about the criteria they take into account when deciding to litigate for financial reasons. 
In both countries, the regions or federal states manage the funds. As subnational actors have the responsibility to issue the funds according to EU law, they are also responsible in cases of detected non-compliance. In practice, this means that the region where funds have been misspent is the one to pay the financial correction back to the Commission. On the other hand, in the ruling Regione Siciliana (C 15/06), the Court made clear that it would not admit annulment actions over financial corrections from subnational authorities. It is very difficult for these subnational authorities to demonstrate the direct effect of supranational decisions. The Court found, for example, that the Commission's decision of financial corrections lacked a direct effect on the applicant region, which is an indispensable criterion for the region, treated as nonprivileged applicant, to have their actions admitted by the Court (see Chapter 3). Hence, annulment actions against decisions of financial corrections should be raised by the member states on behalf of the regions concerned. Therefore, for matters related to the funds, while the regions bear the costs of the Commission's decisions, it is up to the member state to decide whether to litigate. Cooperation between regions and the central state is therefore necessary for litigation to take place.

The regions affected by financial corrections decisions usually want their member state to engage in litigation against the Commission. This material interest rationale for litigation is often paramount for the concerned regions (MIN_DE_5, MIN_ES_4). State-level actors, the central administration responsible for the funds, and the state attorneys are receptive to the region's interests and usually willing to cooperate with the regions on that matter. However, they also consider other criteria and balance them with the financial criteria when deciding whether to litigate or not, such as the legal merits of the case (MIN_DE_5, MIN_ES_4).

We found that financial considerations are driving many of the member states' decisions to litigate against the Commission. In the cases we studied, the higher the level of the financial correction, the more likely becomes a decision to litigate. State attorneys often have to arbitrate between several petitions for litigation. They must manage their workforce wisely, concentrating on those cases of greater significance. Hence, cases involving a high financial correction are more likely to lead to litigation than cases with low financial corrections (MIN_ES_4).

In Germany, the average amount of financial corrections imposed in the last few years in agriculture amounts to about ten million euros each 
year. Compared to the 6.5 billion euros spent in one year, this barely reaches $0.15 \%$ of the funds received. This is a particularly low level of financial corrections compared to other countries. In 2015, France was requested to return 1 billion euros for the period 2008-2012, which corresponds to about $2 \%$ of the forty billion received from the EU in the same period. ${ }^{3}$ This explains why Germany has raised relatively few annulment actions in agriculture compared to other countries (MIN_DE_5).

In Germany, where financial corrections tend to be low, decisions to litigate depend much on the strength of their legal arguments. Given that the financial incentive is not high, German governments are more selective on the cases they bring to court and decide to go only when they have very strong arguments, that is, when they are nearly convinced that they are right and that they will win (MIN_DE_5). By contrast, in Spain, where financial corrections tend to be higher than in Germany, the financial incentive is higher, which reduces the importance of other criteria in the decision to litigate. In the face of a particularly high financial correction (e.g. several hundred million euros), state attorneys go to court anyway, doing their best to carve out of the case at least some legal issues in order to carry out the judicial battle.

\section{The Potato Starch Case (T-557/13)}

The only annulment action raised by Germany in the agriculture sector in the last eight years is the potato starch case. It illustrates the importance of both the financial and legal factors. The potato starch case is based on a misunderstanding between the Commission and German administrative authorities that arose from the way in which the EU regulation had been translated into the German language. The EU allows interventions to stabilize prices of agricultural products. The root of this disagreement was the question over the precise moment at which the German authorities can pay the direct financial aid to the producers. There is a minimal price - regulated by the EU— that applies to the potatoes sold by the potato producer who benefits from EU aids. To make sure the producer does not sell the potatoes below the minimal price, EU regulation stipulates that national authorities can only pay the aid once the producer has received this minimal price for potatoes. German authorities have allowed the application of this requirement in several instalments. The payment for the potatoes is issued in three instalments. The producer first receives $41 \%$ of the minimal price for the potatoes 
delivered; another two instalments complete the payment of the minimal price. Accordingly, the authorities granting the aid have paid $41 \%$ of the aid once the producer has received $41 \%$ of the minimal price, and so on. Arguably, this procedure is in line with the German version of the regulation. Nevertheless, based on the English version of the regulation, the auditors and the Commission claimed there was an irregularity. They argue that the aid can only be paid to the producer once the producer has received the full $100 \%$ of the minimal price for the potatoes produced and delivered. German civil servants, who insisted that the German language version of the regulation was different, rejected this interpretation. Despite the confusion over linguistic differences, the Commission decided to impose the financial correction of 6.3 million euros. This meant a substantial flow of money away from the coffers of the culprit Länder - in that particular case, Brandenburg. German state attorneys and civil servants were convinced that their interpretation was right; hence, they decided to litigate. In fact, Germany won this annulment against the Commission (MIN_DE_5).

\section{Adjustment of Salaries and Pensions of Eurocrats (C-196/12, C-66/12, C-63/12)}

Interests to maintain material benefits are at the heart of conflicts over salaries and work-related benefits running between the EU institutions themselves. At the EU level, the Council decides about the statute of European civil servants. Where direct material interests of the staff working in other institutions such as the EP, the Commission, or the European Investment Bank are negatively affected, they might go to court. Such conflicts already resulted in litigation in the 1970s through mid-1980s, as well as in the early 2000s. More recently, horizontal annulment cases related to such financial interests increased, especially in the wake of the financial crisis. Generally, an adaptation clause for the salaries and pensions of Eurocrats exists. Accordingly, the development of EU salaries links to the development of national wage indices in the EUROSTAT data, with a time lag due to technical requirements for working out the indices. 'And what happened-it was in the middle of the financial crisis - the calculations, which came from the years before, brought a result that was unacceptable for the member states. They said, you couldn't do that. We are asking for budget cuts' (EP_l). Neither 
Commission nor Parliament staff wanted to accept this linkage, and their respective institutions decided to take the Council to court for refusal to adopt the Commission's proposal for salary adjustment. In fact, a number of related cases were successively opened (C-453/12, C-68/13), until the first case was settled in court.

In sum, these cases illustrate the importance of financial motivations when actors decide to file an annulment case against EU institutionsand even between EU institutions themselves. The evidence gleaned from the interviews also underlines that the legal merits of a case-how actors perceive their chances to succeed in court-are duly taken into consideration in the decision of public actors to engage in litigation or not.

\section{Institutional Competences-Driven Motivation in Annulment Litigation}

Annulment actions are also motivated by actors' willingness to maximize (or defend) their decision-making competences. They are driven by actors' institutional interests. Inviting the CJEU to intervene in such cases is a way to obtain an authoritative interpretation of the scope of the defendant's competences, with the hope to prevent competence creep into the litigant's institutional prerogative in the future. Thus, this motivation should be particularly relevant for public actors at the different levels of the EU multilevel governance system.

Our quantitative data highlights that institutional competences are an important motivation behind annulment actions. For example, we observe rises in the number of annulment cases shortly after treaty changes (see Fig. 5.1). After the adoption of new formal rules (marked by the vertical dotted lines), struggles over the interpretation of those rules follow (see also Farrell and Héritier 2007). To settle such conflicts, the actors involved call upon the judiciary to intervene. Such testing the ground and clawing back of competences explain the peaks of annulment litigation in the years following changes of the European treaties. Annulment actions tend to emerge after treaty changes alter the status quo of competence allocation in the EU. We turn now to some case studies that help illustrate the context of actors' strategies to preserve, defend, or obtain institutional competences with the help of annulment litigation. 


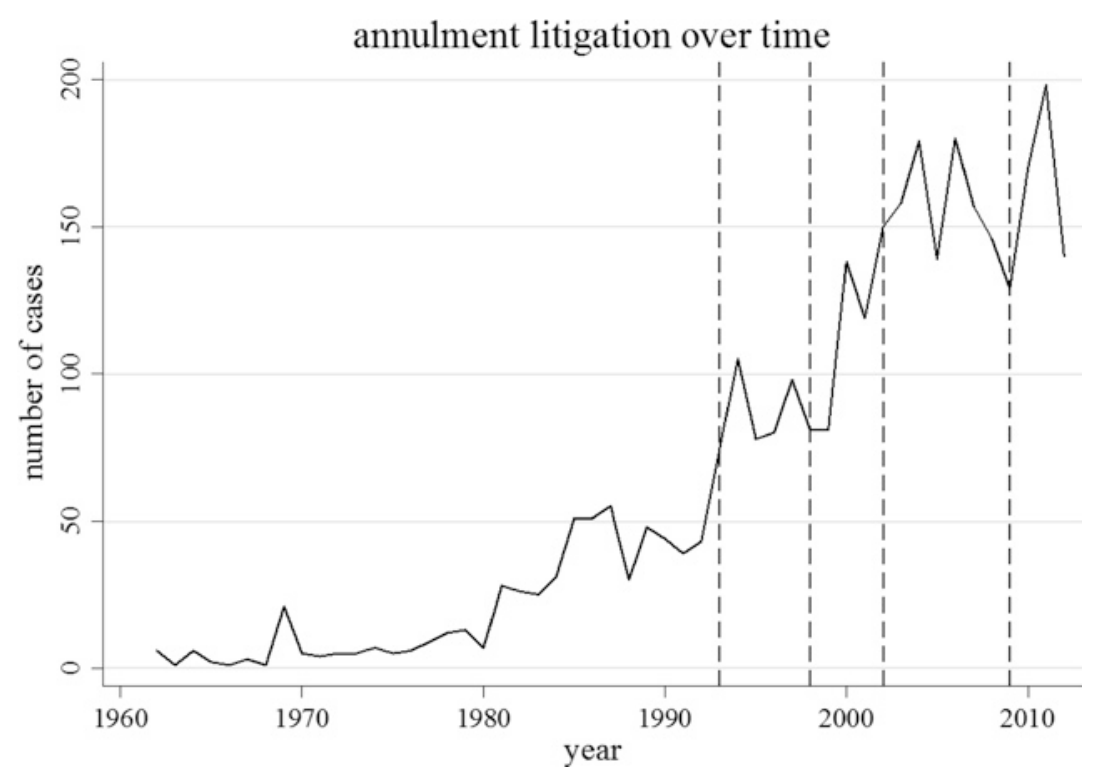

Fig. 5.1 Annulment actions and treaty changes (Source Figure based on own data. Dashed vertical lines indicate the year in which treaty changes came into effect [the Maastricht Treaty in 1993, the Amsterdam Treaty in 1998, the Nice Treaty in 2002, and the Lisbon Treaty in 2009])

\section{The Renewable Energies Law Case (T-134/14 and T-47/15)}

In cases $\mathrm{T}-134 / 14$ and $\mathrm{T}-47 / 15$ that dealt with the promotion of renewable energies in Germany, the motivation of the German government for challenging the Commission's decision derives from the willingness to protect its own institutional competences. The German renewable energy law subsidizes producers of alternative energies. The law guarantees that the electricity produced from renewable energies can be sold at a guaranteed price. The difference between the market price and the price effectively charged is sponsored by consumers. The law designed a financial circuit that transits between several actors (electricity companies, mainly network operators) and passes on the burden of the subsidy to all consumers of electricity. This implies that electricity prices in Germany are relatively high, which is a problem for those industries that consume a lot of electricity, the so-called energy-intensive 
consumers. To reduce the burden of these energy-intensive consumers, the renewable energy law puts up a compensation, which significantly reduces the intensive consumers' participation to the subsidy of renewable energies, compared to what they would pay if they were subjected to the normal regime. The Commission considered this advantage to energy-intensive users as constituting state aid, and Germany challenged this decision before the Court.

An important motivation for German state attorneys and the German administration was to place a limit on what they perceived as a competence creep on the side of the Commission (MIN_DE_6). The dispute was about the interpretation of the notion of state resources, which, according to EU competition law, must be involved in the aid scheme in order to qualify the scheme as illegal state aid. From the German perspective, no state resources were involved. This is because technically, the advantage enjoyed by the energy intensive users stemmed from a regulatory mechanism that passed the costs of the subsidies for renewable energies on to consumers. According to Germany, since the funds travelling in this circuit never transited through any kind of state fund, the criteria of state resources was not met. The Commission had a different perspective. Since the mechanism through which the subsidies are handed out to the final consumers is designed by the state, this is enough to consider that the mechanism constitutes state aid. This reasoning, contained in the controverted decision of the Commission, was new. As such, it represented a new threat for the member states, as its application would greatly broaden the scope of national measures that could be subject to EU state aid law, thereby limiting national room of manoeuvre.

To some extent, Germany's willingness to litigate was motivated by the intention to defend its legislative scheme and specific policy design (MIN_DE_6). Yet the concern with the growing scope of EU state aid law to the detriment of national autonomy has also played an important role in Germany's motivation to challenge the Commission (MIN DE_6). While the case was examined by the Court, Germany prepared an updated version of its renewable energy law, which was negotiated with the Commission in terms of the design of the compensation mechanism for energy-intensive users. The Commission and Germany reached an agreement on a new national law that would enter into force in 2014 . Therefore, Germany's necessity to defend the previous version of the renewable law before the Court faded away, so they could have simply withdrawn the case if their only goal was to protect their renewable 
energy approach. Very importantly, however, the state attorneys deliberately decided to continue to pursue the case. They wanted to have the Court decide on the interpretation of the notion of state resources, hoping to preserve their autonomy (at best) or to clarify the legal situation (at worst) (MIN_DE_6). This decision to continue litigation in order to reach a general clarification in terms of the Commission's powers to limit domestic policy, quite apart from the question of whether the concrete trigger of the case is still relevant or not, shows the general character of annulment litigation strategies. It is not only in defence of a particular policy for which annulment litigation is undertaken. Sometimes, litigation aims at settling the underlying legal issue, which might lead to similar struggles about institutional competences between national governments and the Commission in the future.

\section{The Leipzig Halle Case (T-396/08) and the Dresden Airport Case (T-215/09)}

Cases T-396/08 and T-215/09, which dealt with new runways at the Leipzig Halle and Dresden airports, provide other examples of litigation pursued in order to contain what is perceived as the Commission's competence creep in state aid. In the mid-2000s, the logistics company DHL considered moving its hub from Brussels to Leipzig. To attract DHL, Saxony's government committed itself to building a new runway at the Leipzig Halle airport with priority usage for the company; in case it would fail to do so, the regional government committed itself to compensating the company financially. Saxony notified this arrangement to the Commission in line with EU state aid law. While the agreement specified that DHL would only be compensated financially in case the runway would not be built, this arrangement with DHL could be state-aid relevant. The Commission, however, did not limit its examination of the dossier to the potential financial compensation for DHL. The Commission also assessed whether the building of a runway with priority usage was compatible with EU state aid law. The Commission argued that the building of this new runway by Saxony's government would constitute a state aid in favour of the Leipzig Halle airport. This came as a surprise to Saxony, as only the financial support of economic activities was traditionally perceived as state aid. In this sense, the operation of infrastructure like an airport had always been seen as an economic activity. Consequently, its support with public funds constituted state aid that 
would have to be declared to the Commission and checked for its compatibility with EU law. In contrast, the construction of infrastructure was traditionally not seen as an economic activity. Constructing infrastructure with public funds was thus not perceived as state aid and would thus not have to be examined by the Commission.

Although in this specific case, the Commission found that the building of the runway constituted state aid that was compatible with EU law and authorized the project, Saxony strongly opposed the decision. Most importantly, it did so because it would have significant implications for all future regional infrastructure projects. If one were to accept the Commission's approach towards regional infrastructure projects, all future projects would have to be passed by the Commission. Saxony feared that in the future, the Commission might not be so generous and would decide to cap or deny such projects. At the very least, the need to involve the Commission would definitely lead to a loss of control and time within such projects (MIN_SA_1). Consequently, in 2008, Saxony filed an annulment action against the Commission's decision. Germany's federal government supported Saxony as an intervener in court. In coordination with the Saxon government, the Leipzig Halle airport filed a separate action against the Commission.

A few months after initiating the annulment action over the runway at the Leipzig Halle airport, Saxony decided to also build a new runway at the Dresden airport. This was the perfect opportunity to further escalate this competence struggle with the Commission over the distribution of competences over state aid policy. Therefore, Saxony notified the Commission of the building of the new runway, yet it did so as a nonstate-aid measure. Saxony anticipated that the Commission would reject this notification and qualify the runway again as state aid. This gave Saxony another chance to challenge the Commission's attempt to gain more control over regional infrastructure projects in court via annulment action in March 2009 (MIN_SA_1).

In March 2011, the General Court rejected Saxony's action over the Leipzig Halle runway. Since the Commission had authorized 100\% of the aid, the measure lacked a direct legal effect on Saxony. Moreover, the Court backed the Commission's interpretation of the concept of economic activity in state aid law. Subsequently, the airport appealed the General Court's decision on the Leipzig Halle case and Saxony suspended the Dresden case (which was still pending) until the Court's decision on the appeal in the Leipzig Halle case. In December 2012, the 
Court's final judgement confirmed the General Court's ruling in favour of the Commission and Saxony also withdrew the Dresden case. In light of this case law, there was no longer a realistic chance of winning this case. Both of these airport cases demonstrate rather well that annulment litigation is not always just about the specific policy decisions that these cases deal with legally. Annulment actions are also initiated in order to influence the distribution of competences in the long run. In this sense, annulments are employed strategically in the struggle between actors eager to protect or expand their decision-making powers.

\section{Procedural Competences in Trade Negotiations (C-22/70 and C-425/13)}

External affairs is a policy area that has seen many competence changes and competence conflicts over the last decade of EU integration. New offices have been created, such as the High Representative, and new organizations, including the European External Action Service with its hybrid organizational structure and mix of officials from national foreign services, the Commission, and EU diplomatic corps. While EU external trade policy has been strongly supranationalized, other, closely related issues, such as development aid, have not. In this context of evolving supranational competences, the European Commission, the Council, and even the EP are seeking to keep or expand their specific prerogatives. Early annulment rulings had established the principle of implied powers, which endowed the Commission with negotiation competences in all areas in which the community held internal competences, such as transport (cf. ERTA case C-22/70, see Chapters 1 and 3). Ultimately, this principle got promoted to EU primary law with the Nice Treaty (Cremona 2011). Despite such far reaching and lasting feedback effects in primary law, conflicts about competences continue in an area characterized by fuzzy and overlapping powers (MIN_DE_4). Issues of contention in more recent annulment actions have moved on to the questions of representation (role of the High Representative, C-387/00), as well as to procedural powers - that is, fine-tuning the broader competences set in the treaties, for example reporting rights during international negotiations or duration of negotiation mandates (C-425/13, COM_2). In this case, the Commission sought the annulment of a paragraph in a Council decision of 13 May 2013. The contended paragraph authorized the opening of negotiations that would link the EU emission 
allowances trading scheme with an emission-trading scheme in Australia. The Council decision was modelled on an earlier scheme for emission-allowance trading with another third country, Switzerland. Council competences for opening the negotiations were uncontested. Linking the negotiation mandate to existing schemes would, however, limit the room to manoeuvre in negotiations and was thus contested by the Commission, which insisted in its treaty-based right to negotiate international agreements that do not fall in the area of the Common Foreign and Security Policy without a more detailed Council mandate. From the Commission's perspective, an existing degree of independence wasillegally_challenged with which it can act in negotiations, in particularly vis-à-vis the Council and the EP.

\section{The Selective Tax Benefits Cases (T-219/10, T-399/11)}

The European Commission recently began examining national tax legislation to identify advantages that could result from specific tax provisions, with a view to applying state aid law. Indeed, tax advantages are only granted to some beneficiaries who comply with specific criteria. The extent to which these criteria imply a selective effect can be subject to debate. Yet selectivity is a key criterion in state aid law. Only those provisions that are selective can qualify as state aid.

After a first series of cases related to regional aid in the Basque country in the early 2000s, the Commission confirmed its interest in analysing national tax legislation from a state aid perspective. In the late 2000s, the Commission adopted decisions qualifying national tax provisions as illegal state aid, notably in Spain and Germany. This move surprised the member states, who saw tax legislation as measures of general applicability, deprived of selective effect (MIN_DE_6). Quite importantly, tax policy remains an area of member state sovereignty. EU policy making was characterized by conflict and stalemate. Several annulment actions followed against these decisions, some of them initiated by the member states who were keen to put a halt on the Commission's competence creep. The cases related to tax amortization in Spain are examples of such annulment actions.

There is a Spanish tax scheme that allows companies based in Spain that have acquired shares in a company established abroad to deduct from the basis of assessment for corporate tax in Spain part of the sum paid to acquire the share, corresponding to what is called the financial 
goodwill. The Commission examined this measure and concluded that insofar as it provides a fiscal advantage to those companies that invest abroad, the measure was selective. Hence, the Spanish tax scheme constituted state aid and the corresponding financial advantages granted should be recovered by the state.

Two companies affected, Autogrill and Banco Santander, brought annulment actions against the Commission's decisions (T-219/10, T-399/11) and won in first instance (the judgement was delivered in 2014). Unlike the Commission, the General Court considered that the derogation from the normal tax regime granted to companies investing abroad was not sufficient to find that the measure is selective. The selectivity criterion requires that the beneficiaries of the aid correspond to a category of undertakings that can be distinguished on account of their specific characteristics (e.g. location, sector, etc.). This was not the case here, as any company has the option of realizing an investment abroad.

The Commission appealed the judgements in 2015 (C-20/15 P, $\mathrm{C}-21 / 15 \mathrm{P})$. In the appeal, three countries decided to intervene in the case in support of the companies opposed to the Commission: Spain, Ireland, and Germany. Spain's motivation to intervene in the case was twofold. While Spain was interested in defending its legislation and tax scheme, its decision to intervene was also largely a result of its willingness to oppose the Commission's interpretation of the selectivity criteria and its extensive application to national tax regimes (MIN_ES_5). As for Germany, while the contested measure was a Spanish one, the German government felt concerned because the decision of the Commission threatened to broaden significantly the realm of application of EU state aid law, to the detriment of national autonomy in tax policy in general (MIN_DE_6). Germany's intervention had a clear and explicit purpose: Germany wanted to ring-fence the Commission in the area of tax law. The Court delivered its judgement in 2016, overturning the ruling of the General Court, thus confirming the Commission's broad understanding of the selectivity criteria. As for Ireland, enmeshed in a similar conflict with the Commissions about Irish tax law, as exemplified with the Apple case mentioned in Chapter 1, our document analysis indicates that their intervention in the case was also a result of their willingness to protect their institutional autonomy in the field of tax policy.

In sum, the four cases presented in this section illustrate, in various contexts and constellations, that protecting institutional competences is an important motivation for engaging in annulment actions. 


\section{Ideology-Driven Cases in Annulment Litigation}

According to our conceptualization, actors' decisions to raise an annulment action can be motivated by ideology, that is, the willingness to promote ideological preferences. Ideological drivers are, for example, party political positions or liberal versus interventionist stances on policy designs. In our fieldwork, we regularly encountered ideological considerations leading to or backing up litigation strategies as one factor among others. We present three examples where policy and an ideological motivation were the main reason for launching annulment lawsuits. ${ }^{4}$

\section{The EPSO and Patent Package Cases (T-148/13, T-149/13, T-191/13, C-274/11, C-147/13)}

Spain challenged a decision of the European Personnel Selection Office (EPSO) to publish the call for recruiting staff in EU institutions because it did not include Spanish as a working language. They argued that this constituted discrimination because the language requirements for the competition were lower for those applicants whose mother tongue was either French, German, or English. This action reflects a constant policy line of Spain: fighting to have Spanish recognized as a working language in all EU organizations (MIN_ES_2, MIN_ES_5). Therefore, whenever there is an opportunity to manifest this position before the Court on the subject, the Spanish government goes for it (MIN_ES_2).

The same explanation applies to a series of annulment actions initiated by Spain against the adoption of a European unitary patent package (adopted by the member states in 2012). The translation arrangements for the unitary patent would be discriminatory towards individuals whose mother tongue is neither French, German, nor English because the patents would be granted in French, German, or English only. The Court rejected Spain's actions in 2015.

Italy has an interest similar to Spain's on this topic. Just like Spain, Italian authorities regularly resist decisions of the EU that privilege the three working languages of the EU (French, English, and German) to the detriment of other languages. Just like Spain, the Italian government takes annulment actions against EU institutions in the attempt to promote Italian (C-295/11; T-443/16), as was the case in the negotiation of the European Patent package (Van Zimmeren et al. 2015). 


\section{Passenger Rights (C-317/04 and C-318/04)}

In the aftermath of the $9 / 11$ terrorist attacks, the United States tightened legal requirements for air carriers flying to or over the United States. Accordingly, now passenger name records would have to be communicated to the United States Department of Homeland Security, the Bureau of Customs, and Border Protection US. Aware of the potential clash between this provision and European rules on data privacy, the Commission negotiated an international agreement that led to Commission Decision 2004/535/EC 5 and Council Decision 2004/496/EC. ${ }^{6}$

These internationally negotiated rules, however, collided with the EP's views on data privacy. For nearly a decade, and particularly since the adoption of the first EU data privacy directive, civil liberty rights had been high on the Parliament's agenda (Long and Quek 2002; Newman 2008). From the viewpoint of the EP, the agreements signed with the United States were not merely a setback. The Parliament considered this agreement to be a blunt violation of fundamental individual rights (COM_2). Consequently, the Parliament launched two closely related annulment cases against the Commission (C-318/04) and against the Council (C-317/04). Leaving victorious in both legal actions, the EP was able to defend a policy position that it has since developed further, a prominent example of which was its negotiation of a framework for the processing of personal data with the General Data Protection Regulation. ${ }^{7}$ Given the Parliament's strong preferences for data privacy and its objective to present itself as a defender of civil liberty rights, securing values on civil liberty enshrined in existing policies and preparing the ground for future instruments is a core motivation to go to court. Annulment actions are one important instrument to do so.

\section{The Private Pension Market Case $(C-57 / 95)^{8}$}

This conflict between France and the Commission has roots that reach back to the year 1991, when the Commission submitted to the Council a proposal for a Council directive relating to the freedom of management and investment of funds held by institutions for retirement provision. This proposal represented the first attempt to effectively harmonize the European market for pension funds. While the basic freedoms ensured within the internal market that was to be completed by 1992 was also 
seen-at least by the Commission - to extend to pension funds delivering financial services, these were at that point in time still subjected exclusively to highly diverse national regulation.

The Commission's proposal for a Council directive did not try to abolish the national diversity of pension systems and abstained from forcing member states to allow for the national establishment of pension funds. Yet the proposal nevertheless contained several requirements. Specifically, member states would no longer be allowed to constrain national actors to use the services of pension funds established in other member states (European Commission 1991, Article 3). Furthermore, the proposal defined several principles guiding the investment practice $s$ of pension funds (European Commission 1991, Article 4). In this context, it emphasized, among other things, that member states should no longer prohibit pension funds from investing in foreign securities. Pension funds would thus have a right to choose their investments within the internal market freely.

While the matter was undisputed among actors at the supranational level, the proposal was highly controversial among the member states in the Council, with France being one of its main opponents. Consequently, the Commission decided to withdraw the proposal in 1994. France opposed the proposal not only because it challenged the French approach towards private pension funds, but also-and mainlybecause it challenged the French approach towards regulating investments by institutions for retirement provision. While France was one of the few member states that traditionally defined detailed quantitative investment restrictions, the Commission's proposal rather included qualitative concepts. It specified that assets should be sufficiently diversified, avoid major accumulations of risk, and restrict investment in the sponsoring undertaking (i.e. the company for which the pension fund works to ensure the pensions of its workers) to a prudent level. Instead of relying on strict quantified obligations, this regulatory approach reflects a precautionary principle (or prudent-person rule) that was typically applied in Ireland, the United Kingdom, and the Netherlands but ran counter to the French approach. In 1998, the financial institution Deutsche Bank still diagnosed an ongoing clash of regulatory cultures with respect to investment rules for institutions of retirement provision. The debate between proponents of quantitative restrictions on investment and proponents of the prudent-person rule was at the heart of this conflict (Deutsch 1998; Haverland 2007). 
The Commission, however, did not give up on its intention of laying the foundation for pension fund reform. On the contrary, the Commission simply decided to pursue this objective by different means. Specifically, the Commission quickly moved to publish its interpretation of relevant Community law with respect to rights and obligations of pension funds in the Official Journal. In fact, the Communication on the Freedom of Management and Investment ${ }^{9}$ of funds held by institutions for retirement provision was purposefully published on 17 December 1994, not even two weeks after the proposal for a directive had been withdrawn. Moreover, the connection between the proposed directive and the Communication was not only their temporal proximity. The two texts were also rather similar in content (Hartlapp 2008; Adam 2016).

Thus, unsurprisingly, France quickly decided to initiate an action for annulment against the Communication. The motives driving France to litigate were the same as their motives to prevent the adoption of the directive proposed by the Commission. In the backdrop of the clash of regulatory cultures, the French government wanted to preserve their regulatory approach. They were thus seeking to keep the policy in line with the precautionary principle.

This section presented annulment cases dealing with recruitment practices, the EU's patent package, data privacy, passenger rights, and private pension market reform. These cases illustrate that seeking policies on ideological grounds plays a crucial role in public actors' decisions to engage in annulment litigation.

\section{Political Trust-Driven Annulment Cases}

Seeking to improve, restore, or protect political trust is a common driver of annulment conflicts, especially in multilevel conflicts that pit member states against EU institutions. Where supranational actions clash with public opinion in certain countries or regions, standing up to Brussels can be politically opportune no matter whether legal actions will be successful. Obviously, this motivation of building political trust is particularly important to actors that seek (re-)election. We distinguish three situations in which political trust motivates annulment actions by national governments. National governments may challenge EU institutions to gain trust from citizens, from subnational territorial authorities, or from companies. We illustrate the empirical relevance of these constellations below. 


\section{Toy Safety Case (T-198-12)}

The German case on toy safety illustrates how governments may litigate against the Commission to gain the trust of an important constituency. After a series of problems with toy safety in the mid-1990s, the Commission decided to revise the old EU toy safety regulatory regime established in 1988. The scientific report that the Commission used as a basis to work on the regulatory reform was controversial among the academic community. Based on studies other than those used by the Commission, Germany contested the limit values for lead and other toxins recommended by the Commission, arguing they were too high to guarantee children's health. In other words, Germany considered the Commission's approach to be too lenient and unable to effectively protect child health. Nevertheless, Germany's input was ignored, and a new directive on toy safety was adopted in 2009. This directive was based on the limits for toxic substances as proposed by the Commission.

Once the directive came in force, the obligation to transpose it clashed with the pressure felt by the German government to respond to public opinion concerns. After all, even before the adoption of the directive, the German government had publicly communicated its concerns about the high limits proposed by the Commission. The German Parliament, along with consumer protection groups, scrutinized the topic rather closely. With the directive adopted, all eyes were on Ilse Aigner, Germany's federal minister for consumer protection, to see what she was going to do in order to secure the highest possible protection for German children (MIN_DE_9).

Minister Aigner had two options at the time: Germany could either launch an annulment action against the directive, or it could delay the transposition to negotiate lower limits within comitology. Since Germany disagreed with only about $10 \%$ of the directive's content, Aigner chose the second option. Over time, however, the German government realized that it would not be able to meet its objectives via comitology and technical ex post negotiations, as the concessions made by the Commission to raise the regulatory requirements were still far below German's safety standards. Having missed the chance to litigate against the directive and having failed to negotiate an appropriate compromise, Germany turned to its right-guaranteed by the treaties- to deviate from EU safety standards in case this was deemed necessary to ensure a higher level of health protection. Germany thus made a formal request to 
the Commission for the authorization to introduce stricter limits on toxins in toys than those defined by EU law. Yet in response to the request, the Commission only accepted deviation from EU levels for some toxins but not for others. Here, Germany would still have to comply with EU standards.

Germany's government was divided over this issue. There was disagreement between the Ministry for Consumer Protection and the Ministry for Economic Affairs, and the issue escalated up to the highest political level, the German federal cabinet. The Ministry for Economic Affairs opposed litigation against the Commission's decision for fear that diverging from EU-wide standards could have a negative impact on German toy industry. On the other hand, Minister Aigner was under great pressure to follow-up on her public commitment to do all she could to 'protect German children', even if that meant going to Luxembourg. Aigner won this dispute, and Germany decided to litigate against the Commission. Even though the German government lost this legal conflict in the first instance and its subsequent appeal, it did not lose this conflict politically. The public accepted the sentence and did not punish its leaders, as the blame was successfully shifted to the Commission and the Court. Aigner could be seen as having done her best in 'standing up to Brussels' for a good cause (MIN_DE_9).

\section{The Molluscs Case (T-204/11)}

In all cases related to funds in agriculture and cohesion policies, political trust between the state and its regions plays a central role in the decision to litigate. We explained above that many of these cases were essentially based on financial motivations. Yet when negative financial effects rest on the shoulders of an actor not able to litigate itself, this actor relies on a privileged litigant, such as a member state government, to litigate in its behalf. In Spain, for example, the regions are responsible for carrying financial sanctions imposed by the Commission for inappropriate spending of agriculture funds and cohesion funds. Yet the Court has established a very restrictive approach towards the regions' ability to challenge such financial corrections decisions by the Commission. Therefore, they depend on the national government to endorse their interests and litigate on their behalf. Only when the federal government's budget is affected by such corrections does it have a clear financial motivation to 
litigate. But what is its motivation to litigate if mostly regional budgets are affected? Our interviews suggest that, particularly in Spain, the principle of constitutional loyalty plays an important role in this regard. Maintaining smooth and cooperative relationships with its respective regions or states is of paramount importance for a central government. It is a way to improve or protect the relationship with a specific region. Annulment litigation in this sense is a way to build political trust.

One case that illustrates the relevance of this motivation is the molluscs case. In 2011, the Commission adopted a regulation to change the methodology used for the detection of toxins in bivalve molluscs such as clams and oysters. While the detection of toxins had relied on trials on mice, analyses would now have to rely on chemical procedures. Galicia, a coastal region in northern Spain whose economy relies heavily on the fishing sector (especially on molluscs), opposed this regulation. In particular, this opposition resulted from the fact that this chemical method was much more expensive for the Galician administration and for Galician shell fishermen. Having to switch to this method was portrayed and perceived as a catastrophe for Galicia. Equipped with scientific evidence that questioned the new method, Galicia tried to litigate against the regulation before the CJEU. However, being aware that the restrictive standing rights of regions would likely prevent such an action from being admitted, Galicia decided to turn to the central state for support (MIN_GA_5).

In Spain, this petition is made informally via the day-to-day communication between the relevant ministries of both governmental levels. If the relevant central ministry then endorses the region's interests, it makes a formal petition to the central monitoring commission, which is led by state attorneys. This monitoring commission effectively decides whether Spain will take the matter to court. While this is usually a rather smooth process, the strong clash of interests between Galicia and the national agriculture and health ministries resulted in a rockier process in this particular case. First of all, a Spanish laboratory affiliated with the Spanish national agency for food safety had played a central role in the development of the new chemical methodology adopted at the EU level. Naturally, they defended the advantages of this method (MIN_GA_5). Second, in an informal deal with the European Commission in comitology, Spanish representatives had committed not to challenge the regulation before the Court. In exchange, the European Commission 
agreed to prolong the transition period until the new method became obligatory. The competent ministries at the central level were therefore strongly opposed to litigate, and for this reason, they refused to endorse Galicia's petition before the monitoring commission (MIN_ES_1).

Galicia thus followed the formal procedure to make their petition to the monitoring commission, which is carried out through the intermediation of the Conference for Issues Related to the European Union (CARUE), the commission for the coordination between the central state and the regions about EU issues. Galician representatives were duly invited to present their views before the monitoring commission, which led to a lively technical debate between experts from Galicia and the Spanish food safety agency (MIN_GA_5). Within the monitoring commission, composed of the state attorneys and all central ministries, decisions to litigate are adopted under unanimity. This obviously implies that when one or several ministries oppose the judicial action, there is no litigation. Surprisingly, despite the clear opposition of the central ministries for health and agriculture, the monitoring commission decided to support Galicia.

While the central state acknowledged the deep impact of the regulation on Galician producers and the good legal and technical arguments in favour of an annulment action, these conditions cannot normally justify overcoming the opposition of a central ministry. The decisive factor for this surprising decision was the willingness of the central state to signal a cooperative attitude and good will towards Spanish regions in matters related to interventions before the CJEU. Previously, the CARUE process yielded little support for Spanish regions, as many petitions raised by the regions were rejected. This fuelled substantial resentment, as the regions felt their interests were not duly taken into account, even in such matters for which they held the formal competence according to the Spanish constitution. With its decision to litigate over the method used to test Galician shellfish for toxins, the Spanish central government decided to send a positive signal to the regions to show that their concerns were heard and supported (MIN_ES_1). Once the decision to litigate was taken, Spanish state attorneys and Galician officials worked in close collaboration to defend the case, which they eventually lost, however. 


\section{BMW Case (T-671/14)}

Finally, the $B M W$ case exemplifies the situation where governments use judicial actions to maintain good relationships with certain companies. The German region Saxony wanted to have BMW, the German carmaker, establish its new plant for electric cars in Leipzig and promised the company an aid of forty-nine million euros if they did so. They justified this measure by the EU regime for regional aids, exclusively applicable to Europe's poorer regions. Under the regional aid regime, poor regions only have to notify the Commission of aid that exceeds 22.5 million euros (below this threshold, a block exemption applies; such smaller aids are automatically legal and exempted from notification obligation). Since Saxony wanted to give 49 million to BMW, they however had to notify the Commission of the aid. Before being able to authorize the aid, the Commission assessed whether the aid was in fact necessary to attract the new plant. To do so, it asked BMW to demonstrate that it would have been cheaper for them to set up shop elsewhere. BMW was able to show a document that evaluated that building the new plant in Bavaria was seventeen million euros cheaper than in Saxony without the aid. While this justified Saxony's need to grant aid to attract a new employer to this poorer region, the Commission used this evidence to evaluate the forty-nine million as excessive aid. It concluded that the aid granted by Saxony could not exceed seventeen million euros. Alternatively, it could take advantage of the block exemption regime and give up to 22.5 million euros in aid if they withdrew their notification completely.

Saxony left it up to BMW to decide what to do. The company, which had seventeen million euros in aid guaranteed, preferred to not withdraw the notification and to sue the Commission's decision (the alternative would have been withdrawing the notification and taking advantage of the block exemption to give 22.5 million euros to BMW). Saxony wanted to show support for BMW as they had promised the aid before the intervention of the Commission. It was important for Saxony to signal that the regional government was a reliable partner standing by its financial promises (MIN_SA_1). However, given that Saxony had lost several previous state aid cases-as in the Leipzig Halle case presented above-the regional authorities shied away from a direct annulment appeal. Instead, Saxony decided to join BMW's action as intervener 
before the Court and contracted first-rank law firms in order to bring additional legal expertise to the case in close coordination with the actions of BMW (MIN_SA_1). ${ }^{10}$

The cases presented in this section illustrate the importance of what we conceive of as political trust for public actors when deciding to raise an annulment case. Especially in cases where the national litigant is unlikely to win (given the objective assessment of the legal situation), raising an annulment action can be a strategy for securing political trust from the electorate, from institutional partners (like regions or subnational authorities), and from big companies-no matter what the final outcome of the legal case is going to be.

\section{Conclusion}

Annulment litigation is about politics. Annulment actions are likely to be used when political considerations blend in. Understanding the use of judicial review thus requires going beyond a purely legalistic view of judicial conflicts, particularly since litigation is costly. Actors thus litigate only after some calculation about the potential costs and benefits; this calculation is done on various levels and with complex aims of the litigating actors. Formally winning a case is sometimes only one objective among others, and occasionally, it is not at all the major driver for litigation.

This is not to say that legal factors are irrelevant. They do play a role in actors' decision to engage in litigation rather than trying to exert influence in the political arena. In addition, they structure choices between different legal channels. Legal options provide the opportunity structure in which actors' concrete political calculations take place. However, in contrast to the literature on the economics of litigation (Gould 1973; Posner 1973), which emphasizes the probability of winning as the essential element in litigants' risk-benefit analysis about their decision to litigate, the expectation to win is often only secondary in annulment cases - at least for public actors. The more annulment litigation is pursued for symbolic reasons - that is, as a signal to domestic constituents - the less important success in court becomes to litigants (Adam et al. 2015). Not to be misunderstood; annulment litigants do genuinely seek judicial success. But in terms of the legal merits of the case, the minimum requirements for justifying litigation are rather low. The important analytical consequence of this being so is that the explanatory power of legal factors on public actors' decision to litigate is limited. 
Based on a new conceptualization of actor motivations, this chapter has identified four possible types of motivations that lay behind engaging in annulment litigation. Litigation can be chosen (1) in order to maximize material gains (or minimize financial costs), (2) to preserve political decision rights and to ring-fence the opponent's decision-making competences, (3) to promote ideological and policy preferences, and (4) to signal trustworthiness to addressees of a policy. Not all of these motivations appeared equally frequent. Ideology, for example, found fewer echoes in our cases. Yet all motivations clearly constitute particular types that provide distinct analytical levers to understand annulment actions in the EU multilevel system. What is more, we saw that specific groups of actors are more likely to litigate based on one particular motivation: financial gains are frequently important for private and subnational governments. Signalling trustworthiness and responsiveness, in turn, are objectives of actors that face electoral competition at the subnational, national, or supranational level. Moreover, the motivation to keep or expand institutional competences matters most for public actors that want to protect their role in public decision taking. Finally, ideology matters most for strongly politicized actors, such as social movements (private litigants) or public actors for which demonstrating that they hold a certain position according to party politics is important in preventing loss of legitimacy for their representational role.

We illustrated the four types of motivations in a number of empirical cases. These cases generally represent one dominant motivation type; only a couple of cases show evidence of motivations coexisting with the predominant one. The applicability of our typology appears thus to be on solid empirical grounds. It backs the conclusion that annulment actions are examples of how multilevel policy conflicts in the EU translate into judicial conflicts when the financial, institutional, ideological, or legitimacy stakes are sufficiently high in the eyes of the actors to justify the dedication of administrative resources to litigation. Before this result, the next chapter analyses the factors that make different litigant configurations more or less likely to occur.

\section{Cases Cited}

See Table 5.2. 
Table 5.2 Cases cited in this chapter

\begin{tabular}{|c|c|}
\hline C-317/04; C-318/04 & $\begin{array}{l}\text { Judgment of } 30 \text { May 2006, Parliament p. Council, Joined } \\
\text { Cases C-317/04 and C-318/04, EU:C:2006: } 346\end{array}$ \\
\hline $\mathrm{C}-274 / 11$ & $\begin{array}{l}\text { Judgment of } 16 \text { April 2013, Spain v. Council, C-274/11, } \\
\text { EU:C:2013: } 240\end{array}$ \\
\hline C-295/11 & $\begin{array}{l}\text { Order of } 13 \text { October 2011, Italy p. Council, C-295/11, } \\
\text { EU:C:2011: } 660\end{array}$ \\
\hline $\mathrm{C}-20 / 15 \mathrm{P}$ & $\begin{array}{l}\text { Judgment of } 21 \text { December 2016, Commission v. World Duty } \\
\text { Free Group, C-20/15 P, EU:C:2016: } 981\end{array}$ \\
\hline $\mathrm{C}-21 / 15 \mathrm{P}$ & $\begin{array}{l}\text { Order of } 6 \text { October 2015, Commission p. Banco Santander, } \\
\text { C-21/15 P, EU:C:2015: 674;676 }\end{array}$ \\
\hline T-396/08 & $\begin{array}{l}\text { Judgment of } 8 \text { July 2010, Sachsen and Sachsen-Anhalt v. } \\
\text { Commission, T-396/08, EU:T:2010: } 297\end{array}$ \\
\hline $\mathrm{T}-215 / 09$ & $\begin{array}{l}\text { Order of } 18 \text { March 2013, Sachsen v. Commission, T-215/09, } \\
\text { EU:T:2013: } 132\end{array}$ \\
\hline $\mathrm{T}-219 / 10$ & $\begin{array}{l}\text { Judgment of } 7 \text { November 2014, Autogrill España v. } \\
\text { Commission, T-219/10, EU:T:2014: } 939\end{array}$ \\
\hline $\mathrm{T}-204 / 11$ & $\begin{array}{l}\text { Judgment of } 11 \text { February 2015, Spain v. Commission, } \\
\text { T-204/11, EU:T:2015: } 91\end{array}$ \\
\hline $\mathrm{T}-399 / 11$ & $\begin{array}{l}\text { Judgment of } 5 \text { December 2014, Banco Santander v. } \\
\text { Commission, T-399/11, EU:T:2014: } 938\end{array}$ \\
\hline T-198-12 & $\begin{array}{l}\text { Judgment of } 14 \text { May 2014, Germany v. Commission, } \\
\text { T-198/12, EU:T:2014: } 251\end{array}$ \\
\hline $\mathrm{T}-148 / 13$ & $\begin{array}{l}\text { Order of } 15 \text { October 2013, Spain p. Commission, T-148/13, } \\
\text { EU:T:2013: } 564\end{array}$ \\
\hline $\mathrm{T}-149 / 13$ & $\begin{array}{l}\text { Order of } 15 \text { October 2013, Spain v. Commission, T-149/13, } \\
\text { EU:T:2013: } 561\end{array}$ \\
\hline $\mathrm{T}-191 / 13$ & Application of 5 April 2013, Italy and Spain p. Commission, \\
\hline $\mathrm{T}-124 / 13$ & $\begin{array}{l}\text { Joined Cases T-124/13 and T-149/13, Official Journal } 389 \text {, } \\
23.11 .2015 \text {, pp. } 29-30\end{array}$ \\
\hline $\mathrm{C}-147 / 13$ & $\begin{array}{l}\text { Judgment of } 5 \text { May 2015, Spain v. Council, C-147/13, } \\
\text { EU:C:2015: } 299\end{array}$ \\
\hline $\mathrm{T}-557 / 13$ & $\begin{array}{l}\text { Judgment of } 24 \text { September 2015, Germany v. Commission, } \\
\text { T-557/13, EU:T:2015: } 682\end{array}$ \\
\hline $\mathrm{T}-134 / 14$ & $\begin{array}{l}\text { Order of } 8 \text { June 2015, Germany v. Commission, T-134/14, } \\
\text { EU:T:2015: } 392\end{array}$ \\
\hline $\mathrm{T}-47 / 15$ & $\begin{array}{l}\text { Judgment of } 10 \text { May 2016, Germany v. Commission, T-47/15, } \\
\text { EU:T:2016: } 281\end{array}$ \\
\hline $\mathrm{T}-443 / 16$ & $\begin{array}{l}\text { Application of } 9 \text { August 2016, Italy p. Commission, Official } \\
\text { Journal C } 371,10.10 .2016 \text {, pp. } 21-22\end{array}$ \\
\hline $\mathrm{T}-671 / 14$ & $\begin{array}{l}\text { Judgment of } 12 \text { September } 2017, B M W \text { v. Commission, } \\
\text { T-671/14, EU:T:2017: } 599\end{array}$ \\
\hline
\end{tabular}




\section{Notes}

1. In other words, while we expect to find cases explained by, for example, both motivation 1 and motivation 2 , we do not expect to find cases explained by one motivation that would be a hybrid between motivation 1 and 2. In our conception, whereas our motivations can coexist in a single annulment case, they could not be mixed into hybrid types.

2. For example, Eisenberg (1990).

3. Le Figaro, La France va devoir rendre un milliard d'euros d'aides agricoles (27 January 2015), accessed 22 January 2017.

4. In addition, the annulment action initiated over pension market reform in France described by Adam (2016) can also be read as evidence for the relevance of ideological motivations.

5. 2004/535/EC:Commission Decision of 14 May 2004 on the adequate protection of personal data contained in the Passenger Name Record of air passengers transferred to the United States' Bureau of Customs and Border Protection (notified under document number C[2004] 1914), Official Journal L 235, 6.7.2004, pp. 11-22.

6. 2004/496/EC:Council Decision of 17 May 2004 on the conclusion of an Agreement between the European Community and the United States of America on the processing and transfer of PNR data by Air Carriers to the United States Department of Homeland Security, Bureau of Customs and Border Protection, Official Journal L 183, 20.5.2004, p. 83.

7. Regulation (EU) 2016/679 of the European Parliament and of the Council of 27 April 2016 on the protection of natural persons with regard to the processing of personal data and on the free movement of such data, and repealing Directive 95/46/EC (General Data Protection Regulation), Official Journal L 119, 4.5.2016, pp. 1-88.

8. A more detailed description of this case can be found in Adam (2016).

9. COMMISSION, E. C. 1994. Commission Communication on the Freedom of Management and Investment of Funds held by Institutions for Retirement Provision (94/C 360/08). Official Journal of the European Communities, 1994, pp. 7-11.

10. At the time of writing, the case was still pending.

\section{REFERENCES}

Adam, C. (2016). The politics of judicial review: Supranational administrative acts and judicialized compliance conflict in the EU. Basingstoke, UK: Palgrave Macmillan.

Adam, C., Bauer, M. W., \& Hartlapp, M. (2015). It's not always about winning: Domestic politics and legal success in EU annulment litigation. Journal of Common Market Studies, 53(2), 185-200. 
Aiken, K. D., Liu, B. S., Mackoy, R. D., \& Osland, G. E. (2004). Building internet trust: Signalling through trustmarks. International Journal of Internet Marketing and Advertising, 1(3), 251-267.

Amaral, D. A., \& Neave, D. G. (2009). On Bologna, weasels and creeping competence. In A. Amaral, G. Neave, C. Musselin, \& P. Maassen (Eds.), European integration and the governance of higher education and research (pp. 281299). Dordrecht, The Netherlands: Springer.

Bacharach, M., \& Gambetta, D. (2001). Trust in signs. In K. Cook (Ed.), Trust in society (pp. 148-184). New York: Sage.

Baier, G. (2006). Courts and federalism: Judicial doctrine in the United States, Australia, and Canada. Vancouver, BC: University of British Columbia Press.

Baker, L. A., \& Young, E. A. (2001). Federalism and the double standard of judicial review. Duke Law Journal, 51(1), 75-164.

Bauer, M. W., \& Becker, S. (2014). The unexpected winner of the crisis: The European Commissions strengthened role in economic governance. Journal of European Integration, 36(3), 213-229.

Bauer, M. W., \& Hartlapp, M. (2010). Much ado about money and how to spend it! Analysing 40 years of annulment cases against the European Union Commission. European Journal of Political Research, 49, 202-222.

Bebchuk, L. A. (1984). Litigation and settlement under imperfect information. The RAND Journal of Economics, 15(3), 404-415.

Becker, S., Bauer, M. W., \& De Feo, A. (Eds.). (2017). The new politics of the European Union budget. Nomos Publisher: Baden-Baden, Germany: Nomos (Series Studies on the European Union).

Bourdieu, P. (1991). La représentation politique. Elements pour une théorie du champ politique. Actes de Recherche En Sciences Sociales, 36-37, 3-24.

Boutcher, S. A. (2013). Law and social movements: It's more than just litigation and courts. Blog Post. https://mobilizingideas.wordpress. com $/ 2013 / 02 / 18 /$ law-and-social-movements-its-more-than-just-litigationand-courts/. Accessed 9 March 2017.

Brennan, G., \& Buchanan, J. M. (1980). The power to tax: Analytic foundations of a fiscal constitution. Cambridge, UK: Cambridge University Press.

Burley, A.-M., \& Mattli, W. (1993). Europe before the court: A political theory of legal integration. International Organization, 47(1), 41-76.

Camia, V., \& Caramani, D. (2012). Family meetings: Ideological convergence within party families across Europe, 1945-2009. Comparative European Politics, 10(1), 48-85.

Chanley, V. A. (2002). Trust in government in the aftermath of $9 / 11$ : Determinants and consequences. Political Psychology, 23(3), 469-483.

Chanley, V. A., Rudolph, T. J., \& Rahn, W. M. (2000). The origins and consequences of public trust in government: A time series analysis. Public Opinion Quarterly, 64(3), 239-256. 
Christensen, T., \& Laegreid, P. (2005). Trust in government: The relative importance of service satisfaction, political factors, and demography. Public Performance and Management Review, 28(4), 487-511.

Cichowski, R. A. (2007). The European court and civil society. Cambridge, UK: Cambridge University Press.

Citrin, J. (1974). Comment: The political relevance of trust in government. American Political Science Review, 68(3), 973-988.

Citrin, J., \& Green, D. P. (1986). Presidential leadership and the resurgence of trust in government. British Journal of Political Science, 16(4), 431-453.

Coleman, J. S. (1994). Foundations of social theory. Cambridge, MA: Harvard University Press.

Cremona, M. (2011). External relations and external competences of the European Union: The emergence of an integrated policy. In P. Craig \& G. de Burca (Eds.), The Evolution of EU Law (pp. 217-268). Oxford, UK: Oxford University Press.

Davis, D. W., \& Silver, B. D. (2004). Civil liberties vs. security: Public opinion in the context of the terrorist attacks on America. American Journal of Political Science, 48(1), 28-46.

De Swaan, A. (1973). Coalition theories of democracy. New York: Harper and Row.

Deutsch, K. G. (1998). Aktuelle Themen: Perspektiven einer EU-Richtlinie zu Pensionsfonds. Deutsche Bank Research Bulletin, 103, 1-10.

Downs, A. (1957). An economic theory of democracy. New York: Harper and Row.

Downs, A. (1967). Inside bureaucracy. Santa Monica, CA: RAND.

Ege, J., Bauer, M. W., \& Becker, S. (2018). The European Commission in turbulent times: Assessing organizational change and policy impact. Baden-Baden, Germany: Nomos.

Eisenberg, T. (1990). Testing the selection effect: A new theoretical framework with empirical tests. The Journal of Legal Studies, 19, 337-358.

Farrell, H., \& Héritier, A. (2007). Contested competences in the European Union. West European Politics, 30(2), 227-243.

Galanter, M. (1974). Why the "haves" come out ahead: Speculations on the limits of legal change. Law and Society Review, 9(1), 95-160.

Gambetta, D. (1998). Trust: Making and breaking cooperative relations. Hoboken, NJ: Blackwell.

Gil Ibañez, A. (1998). Commission tools for the supervision and enforcement of EC Law other than Article 169 EC Treaty: An attempt at systematization (Jean Monnet Working Papers No. 12/98).

Gould, J. P. (1973). The economics of legal conflicts. Journal of Legal Studies, 2(2), 279-300.

Granger, M. (2004). When governments go to Luxembourg...: The influence of governments on the European Court of Justice. European Law Review, 29, $1-31$. 
Hadfield, G. K. (1994). Judicial competence and the interpretation of incomplete contracts. The Journal of Legal Studies, 23(1), 159-184.

Hartlapp, M. (2008). Intra-Kommissionsdynamik im policy-making. EU-Politiken angesichts des demographischen Wandels. Politische Vierteljabresschrift 40 (PVS-Sonderheft 2007/2), 139-160.

Hartlapp, M. (2015). Politicization of the European Commission. When, how and with what impact? In M. W. Bauer \& J. Trondal (Eds.), The Palgrave handbook of the European administrative system (pp. 145-160). Basingstoke, UK: Palgrave.

Haverland, M. (2007). When the welfare state meets the regulatory state: EU occupational pension policy. Journal of European Public Policy, 14(6), 886-904.

Hetherington, M. J. (1998). The political relevance of political trust. American Political Science Review, 92(4), 791-808.

Hetherington, M. J. (2005). Why trust matters: Declining political trust and the demise of American liberalism. Princeton, NJ: Princeton University Press.

Hetherington, M. J., \& Rudolph, T. J. (2008). Priming, performance, and the dynamics of political trust. The Journal of Politics, 70(2), 498-512.

Hooghe, L., \& Marks, G. (2009). A postfunctionalist theory of European integration: From permissive consensus to constraining. British Journal of Political Science, 39(1), 1-23.

Hughes, C. E. (1928). The Supreme Court of the United States: Its foundation, methods and achievements. Washington, DC: Beard Books.

Hutter, S., \& Grande, E. (2014). Politicizing Europe in the national electoral arena: A comparative analysis of five West European countries, 1970-2010. Journal of Common Market Studies, 52(5), 1002-1018.

Jupille, J. (2007). Contested procedures: Ambiguities, interstices and EU institutional change. West European Politics, 30(2), 301-320.

Keele, L. (2007). Social capital and the dynamics of trust in government. American Journal of Political Science, 51(2), 241-254.

Levi, M., \& Stoker, L. (2000). Political trust and trustworthiness. Annual Review of Political Science, 3(1), 475-507.

Lijphart, A. (1999). Patterns of democracy: Government forms and performance in thirty-six countries. New Haven, CT: Yale University Press.

Lobel, J. (1994). Losers fools and prophets: Justice as struggle. Cornell Law Review, 80, 1331-1421.

Lobel, J. (1995). Losers fools and prophets: Justice as struggle. Cornell Law Review, 80, 1331-1421.

Long, W. J., \& Quek, M. P. (2002). Personal data privacy protection in an age of globalization: The US-EU safe harbor compromise. Journal of European Public Policy, 9, 325-344.

Macoubrie, J. (2006). Nanotechnology: Public concerns, reasoning, and trust in government. Public Understanding of Science, 15(2), 221-241. 
Maor, M., Gilad, S., \& Bloom, P. B.-N. (2013). Organizational reputation, regulatory talk, and strategic silence. Journal of Public Administration Research and Theory, 23(3), 581-608.

McCann, M. W. (1994). Rights at work: Pay equity reform and the politics of legal mobilization. Chicago: University of Chicago Press.

McCann, M. W. (1998). How does law matter for social movements? In B. G. Garth \& A. Sarat (Eds.), How does law matter? Evanston, IL: Northwestern University Press.

Miller, A. H. (1974). Political issues and trust in government: 1964-1970. The American Political Science Review, 68(3), 951-972.

Mishler, W., \& Rose, R. (2001). What are the origins of political trust? Testing institutional and cultural theories in post-communist societies. Comparative Political Studies, 34(1), 30-62.

Moravcsik, A. (1991). Negotiating the single European act: National interests and conventional statecraft in the European Community. International Organization, 45(1), 9-56.

Müller, W. C., \& Strøm, K. (1999). Policy, office, or votes? How political parties in Western Europe make hard decisions. Cambridge, UK: Cambridge University Press.

NeJaime, D. (2011). Winning through losing. Iowa Law Review, 96, 941-1012.

Newman, A. L. (2008). Building transnational civil liberties: Transgovernmental entrepreneurs and the European data privacy directive. International Organization, 62(1), 103-130. https://doi.org/10.1017/ S0020818308080041.

Newton, K., \& Norris, P. (1999). Confidence in public institutions: Faith, culture or performance? Presented at the American Political Science Association, Atlanta, GA.

Niskanen, W. A. (1971). Bureaucracy and representative government. Chicago: Transaction Publishers.

Pollack, M. A. (1994). Creeping competence: The expanding agenda of the European Community. Journal of Public Policy, 14(2), 95-145.

Posner, R. A. (1973). An economic approach to legal procedure and judicial administration. Journal of Legal Studies, 2(2), 399-458.

Prechal, S. (2010). Competence creep and general principles of law. Review of European Administrative Law, 3(1), 5-22.

Priest, G. L., \& Klein, B. (1984). The selection of disputes for litigation. The Journal of Legal Studies, 13(1), 1-55.

Rauh, C. (2019). EU politicization and policy initiatives of the European Commission: The case of consumer policy. Journal of European Public Policy, 26(3), 1-22.

Risse, T., Engelmann-Martin, D., Knope, H.-J., \& Roscher, K. (1999). To euro or not to euro? The EMU and identity politics in the European Union. European Journal of International Relations, 5(2), 147-187. 
Rudolph, T. J., \& Evans, J. (2005). Political trust, ideology, and public support for government spending. American Journal of Political Science, 49(3), 660-671.

Ryan, E. (2011). Negotiating federalism. Boston College Law Review, 52(1), $1-136$.

Scheingold, S. (1974). The politics of rights: Lawyers, public policy, and social change. New Haven, CT: Yale University Press.

Schmidt, S. K. (1998). Commission activism: Subsuming telecommunications and electricity under European competition law. Journal of European Public Policy, 5(1), 169-184.

Segovia Arancibia, C. (2008). Political trust in Latin America. Ph.D. thesis, University of Michigan.

Shapiro, M. (1964). Political jurisprudence. Kentucky Law Journal, 52, 294-345.

Skiadas, D. V. (2002). Judicial review of the budgetary authority during the enactment of the European Unions Budget (SSRN Scholarly Paper No. ID 302757). Rochester, NY: Social Science Research Network.

Stone Sweet, A. (1999). Judicialization and the construction of governance. Comparative Political Studies, 32(2), 147-184.

Stone Sweet, A., \& Brunell, T. L. (1998). Constructing a supranational constitution: Dispute resolution and governance in the European Community. American Political Science Review, 92(1), 63-81.

Swenden, W. (2006). Federalism and regionalism in Western Europe: A comparative and thematic analysis. Basingstoke: Palgrave.

Van De Walle, S., \& Bouckaert, G. (2003). Public service performance and trust in government: The problem of causality. International Journal of Public Administration, 26(8-9), 891-913.

van Zimmeren, E., Mathieu, E., \& Verhoest, K. (2015). The interaction between agencies, networks and the European Commission in emerging regulatory constellations: A comparative analysis of the European telecom sector and the European patent system. In E. Ongaro (Ed.), Multi-level governance: The missing linkages (pp. 125-162). Bingley, UK: Emerald.

Weatherill, S. (2004). Competence creep and competence control. Yearbook of European Law, 23(1), 1-55. 
Open Access This chapter is licensed under the terms of the Creative Commons Attribution 4.0 International License (http://creativecommons.org/licenses/ by $/ 4.0 /$ ), which permits use, sharing, adaptation, distribution and reproduction in any medium or format, as long as you give appropriate credit to the original author(s) and the source, provide a link to the Creative Commons license and indicate if changes were made.

The images or other third party material in this chapter are included in the chapter's Creative Commons license, unless indicated otherwise in a credit line to the material. If material is not included in the chapter's Creative Commons license and your intended use is not permitted by statutory regulation or exceeds the permitted use, you will need to obtain permission directly from the copyright holder.

(c) (1) 